\title{
The effectiveness of topical negative pressure in the treatment of pressure ulcers: a literature review
}

\author{
Mark van den Boogaard • Erik de Laat • \\ Paul Spauwen • Lisette Schoonhoven
}

Received: 4 August 2007 / Accepted: 19 December 2007 / Published online: 19 February 2008

(C) The Author(s) 2008

\begin{abstract}
The objective of the study was to gain insight into the effectiveness of vacuum-assisted closure (VAC) therapy or, more particularly, topical negative pressure (TNP) in the treatment of pressure ulcers. We carried out a systematic search in Medline, Embase and Cinahl for Randomized Clinical Trials (RCTs) involving topical negative pressure in pressure ulcers over the period 1992-2007. Five RCTs were included. Two studies dealt exclusively with pressure ulcers. No significant differences in wound healing were found in these studies. Three other studies (mixed etiology of wounds) did show significant differences in wound healing, in the decrease of wound treatment time, and in the decrease in number of bacteria. The quality of these studies, both in terms of methodology and otherwise, did not always match with the scientific standard. Moreover, these studies lacked subgroup analyses. The analyzed studies described positive effects of TNP, although both the control treatment and the end points varied in these studies. On the basis of the systematic assessment of these five RCTs, the conclusion is that TNP has not proven to be more effective than various control interventions. The differences between and within the studies in terms of control interventions, the differences in randomization and a number of weaknesses in the analyses do not allow a good comparison. The main recommendations for follow-up studies include: randomization of patients rather than of wounds, a homogeneous patient
\end{abstract}

M. van den Boogaard $(\triangle) \cdot$ E. de Laat $\cdot$ P. Spauwen ·

L. Schoonhoven

Intensive Care, Radboud University Nijmegen Medical Centre,

P.O. Box 9101, Internal Post 596,

$6500 \mathrm{HB}$ Nijmegen, The Netherlands

e-mail: m.vandenboogaard@ic.umcn.nl population, the use of a single well-defined and procedurally documented control intervention, and prior calculation of the random sample size.

Keywords Topical negative pressure $\cdot$ Pressure ulcers . Vacuum assisted closure therapy

\section{Introduction}

Despite all the attention given to pressure ulcer prevention, the prevalence of pressure ulcers in the Western world remains high. Depending on the type of health care institution, prevalence lies between $13 \%$ and $35 \%$ [1, 6, 9, 12, 31]. Pressure ulcers cause patients considerable pain and discomfort. Moreover, the costs of preventing and treating pressure ulcers are enormous and lie between $1 \%$ and $4 \%$ of the total budget for national health care $[5,32]$. It is therefore essential that the resources and products for pressure ulcer prevention and management are employed only if their effectiveness has been proven. Over the past few decades, several studies have been conducted on pressure ulcer prevention, the results of which have been used to draw up a number of guidelines for pressure ulcer prevention [9, 12]. However, the scientific underpinning of pressure ulcer treatments is rather thin [9]. Serious pressure ulcers are now more and more treated with the help of vacuum therapy. Vacuum therapy is a recent wound treatment method that has been used since the early $1990 \mathrm{~s}$ for acute and chronic wounds [2, 14, 23, 24]. In practice, vacuum therapy is commonly known as vacuum-assisted closure (VAC) and is associated with a specific supplier. Topical negative pressure (TNP) is a more neutral term that better represents the nature of the treatment and that is the reason why we chose to use this term in this article. 


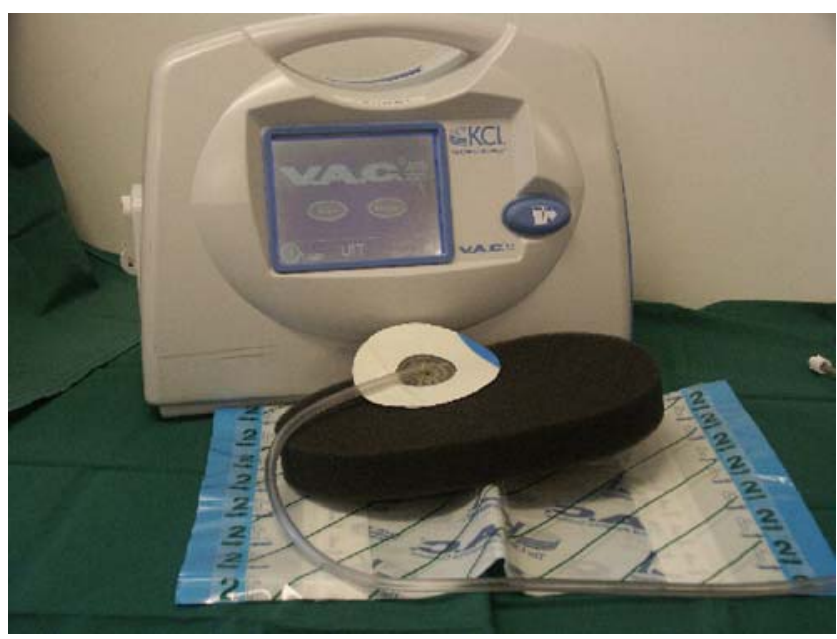

Fig. 1 The VAC or TNP unit

In TNP therapy, a sterile, cut-to-size foam suction dressing is placed in the wound and brought into direct contact with all parts of the wound $[2,23,24,36]$. The foam suction dressing has an open cell structure and a pore size of $0.2-1 \mathrm{~mm}$. By means of a drain in or on the foam suction dressing, the dressing is connected to a vacuum source (see Fig. 1). The wound is taped air-tight using sticky polyurethane foil, which extends everywhere up to at least $2 \mathrm{~cm}$ outside the circumference of the wound. As a result of the open structure of the foam suction dressing, the vacuum is evenly distributed across the entire wound. The mechanical traction that is applied to the wound bed as a result of the vacuum has a positive effect on the wound healing process and leads to $[4,24,34]$ :

1. stimulation of granulation tissue formation [16],

2. decrease in matrix metalloproteinases (MMPs) [16],

3. stimulation of angiogenesis [16],

4. decrease in edema formation, resulting in improved blood flow [19],

5. decrease in bacterial colonization [10, 27-29].

The effect and anticipated effectiveness of TNP in the treatment of pressure ulcers has been described in analytical articles [34] and case studies [8, 17, 30]. The results of a cohort study on TNP and hydrocolloid and alginate products [33] seem to indicate that TNP is more effective in healing pressure ulcers. Three prospective clinical trials $[2,11,28]$ involving pressure ulcers show that TNP contributes positively to the healing of pressure ulcers. However, these were not controlled and randomized studies.

A review performed by Evans and Land [13] to assess the effectiveness of TNP in chronic wounds with, for instance, pressure ulcers, showed that there was more need for well-designed randomized controlled trials (RCTs).

Randomized controlled studies are considered the gold standard for effective research.
The aim of this systematic review is to formulate a conclusion on the basis of randomized clinical studies as to the effectiveness of TNP in the treatment of pressure ulcers.

\section{Method}

The literature was systematically searched for randomized controlled clinical studies on the effect of TNP in the treatment of pressure ulcers.

Search strategy

The Medline, Embase, and Cinahl databases (1992-2007) were systematically searched, according to the Cochrane Handbook for Systematic Reviews of Interventions, using the term 'vacuum-assisted closure' and common synonyms: 'VAC'-'vacuum sealing technique'-'vacuum sealing''negative pressure wound therapy'-'subatmospheric pressure therapy'-'foam suction dressing'-'topical negative pressure'- 'TNP'. These keywords were combined with the words: 'decubitus' - 'pressure ulcer(s)' - 'pressure sore(s)'-'chronic wound(s)'. For each database that was used, from a structured thesaurus (for example, Medical Subject Headings $[\mathrm{MeSH}]$ ) appropriate indexing words are chosen. Researchers in the field were contacted for the identification of relevant unpublished data without any result. Furthermore, references to TNP in all the available literature were checked for references to RCTs. There were no language or publication restrictions.

\section{Selection criteria}

All RCTs were included in which TNP was compared with a control intervention in patients with pressure ulcers.

Articles were included if they met the following inclusion criteria:

- the group of examined patients consists entirely or partly of patients with pressure ulcers,

- the outcome measurement is in any case wound healing in terms of volume and or surface reduction or increase in granulation tissue,

- the control intervention has been described.

Data collection and analysis

The first author $(\mathrm{MvdB})$ screened the articles on title and abstract for eligibility on the basis of the inclusion and exclusion criteria. All articles included were independently and full text analyzed by the first two authors $(\mathrm{MvdB}$ and EdL) for the quality of the trials and the narrative synthesis. The Dutch Cochrane quality criteria for the assessment of RCTs were used for the analysis (see Table 1). 
Table 1 Assessment of the quality of the RCTs

\begin{tabular}{lllll}
\hline & $\begin{array}{l}\text { Ford } \\
\text { et al. [15] }\end{array}$ & $\begin{array}{l}\text { Wanner } \\
\text { et al. [35] }\end{array}$ & $\begin{array}{l}\text { Joseph } \\
\text { et al. [18] }\end{array}$ & $\begin{array}{l}\text { Braakenburg } \\
\text { et al. [7] }\end{array}$ \\
\hline [25-27]
\end{tabular}

http://www.cochrane.nl/index.html

$+:$ the quality criteria were met, - : the quality criteria were not met, ?: unclear or not described

\section{Results}

The systematic search strategy yielded a total of 319 articles. Five articles were included and 314 articles were excluded because they were not RCTs. One study was the subject of three published articles [25-27]; these were assessed and counted as one RCT.

Characteristics of the studies

Two of the studies included only patients with pressure ulcers $[15,35]$. The other three also involved patients with other types of wounds [7, 18, 25-27]. The assessment of the methodological quality of the studies can be found in Table 1, while the execution of the studies and the results are presented in Table 2. In all cases, the intervention treatment was TNP using the VAC technology of KCI Medical Products. In all cases, the vacuum was set at $125 \mathrm{mmHg}$ and the dressings were changed every 2-3 days $[7,15,18,25-27]$ or every 2-7 days [35].

The primary end points for wound healing were duration up to the reached end point of wound healing [7, 25-27], decrease in wound volume [15, 18, 35] or decrease in wound surface $[7,25,27]$, sufficient granulation tissue for surgical correction [25, 27], sufficient granulation tissue for further secondary healing [25, 27], pain [7], and bacteria growth [7]. Secondary end points were bacterial cleaning $[25,27]$, wound care time [26], costs of wound treatment [26], comfort [7], and adverse effects [7].

\section{Control treatment}

The control treatment consisted of gauzes wetted in a saline solution [18] or Ringer's solution [35]. Mouës et al. [25-27] used sodium hypochlorite, acetic acid [27], or nitrofuralum [27] as control intervention. In accordance with a decision tree, Ford et al. [15] used two different chemical debridements: a papain-urea ointment or a cadexomer-iodine impregnated dressing. Also in the study by Braakenburg et al. [7], in accordance with a hospital protocol and depending on the contamination of the wound, different dressing therapies were used: hydrocolloid, alginate, acetic acid, or sodium hypochlorite.

Quality of the studies

In all five studies, the wound treatment was randomized with an acceptable follow-up of patients. The studies did not all meet the other quality criteria or were not clear about the other criteria. None of the studies blinded the patients, the physicians, or the nurses for the treatment. The effect assessors of the treatment were completely or partly blinded in most studies [7, 15, 18, 25-27].

In two studies, the study groups were not comparable at the start of the trial. In one study, there was a difference in wound size [35]; and in the other study [25, 27], there was a significant difference in comorbidity between the two groups, all in disadvantage of the intervention group.

Only one study explicitly described the standardization of the treatment given beside the wound treatment [18] (see Table 1).

The study by Ford et al. [15] has a number of significant shortcomings. The random sample size was not based on a power analysis and, furthermore, the distribution of the number of patients or wounds across the intervention or control group was not stated for this randomized study. Of the 28 patients with a total of 41 wounds who were included in the study, 22 patients with a total of 35 wounds 
Table 2 Execution and results of the RCTs

\begin{tabular}{|c|c|c|c|c|c|c|}
\hline & Patients & $\begin{array}{l}\text { Prior sharp } \\
\text { debridement }\end{array}$ & Follow-up & Intervention & End point(s) & $p$ value $(<0.05)^{*}$ \\
\hline $\begin{array}{l}\text { Ford et al. } \\
{[14], 2002}\end{array}$ & $\begin{array}{l}N=28 \\
\text { patients }(41 \\
\text { pressure } \\
\text { ulcers grade } \\
3-4)\end{array}$ & i.n. & 6 weeks & $\begin{array}{l}\text { TNP vs } \\
\text { cadexomer- } \\
\text { iodine or } \\
\text { papain-urea }\end{array}$ & $\begin{array}{l}\text { 1-wound volume; } \\
2 \text {-wound length, } \\
\text { width depth; 3-PMNs, } \\
\text { lymphocytes, and } \\
\text { capillaries }\end{array}$ & $\begin{array}{l}1-p=0.46 ; 2-p=0.10- \\
0.11-0.90 ; 3-p=0.13- \\
0.41-0.75\end{array}$ \\
\hline $\begin{array}{l}\text { Wanner } \\
\text { et al. [34], } \\
2003\end{array}$ & $\begin{array}{l}N=22 \\
\text { patients }(22 \\
\text { pressure } \\
\text { ulcers grade } \\
3-4)\end{array}$ & $\begin{array}{l}\text { Always } \\
\text { surgical } \\
\text { debridement }\end{array}$ & $\begin{array}{l}\text { Achieved } 50 \% \\
\text { wound volume } \\
\text { reduction }\end{array}$ & $\begin{array}{l}\text { TNP vs } \\
\text { Ringer's } \\
\text { solution }\end{array}$ & $\begin{array}{l}\text { Wound volume } \\
\text { measurement (weekly) }\end{array}$ & $p=0.20$ \\
\hline $\begin{array}{l}\text { Joseph et al. } \\
{[17], 2000}\end{array}$ & $\begin{array}{l}N=24 \\
\text { patients }(36 \\
\text { chronic } \\
\text { wounds, } \\
\text { whereof } 28 \\
\text { pressure } \\
\text { ulcers grade } \\
\text { 3-4) }\end{array}$ & i.n. & $\begin{array}{l}\text { Complete wound } \\
\text { healing, follow- } \\
\text { up } 6 \text { weeks } \\
\text { max. }\end{array}$ & $\begin{array}{l}\text { TNP vs saline } \\
\text { solution }\end{array}$ & $\begin{array}{l}\text { 1a-wound volume, b- } \\
\text { depth, c-width, and } \\
\text { d-length }\end{array}$ & $\begin{array}{l}1 \mathrm{a}-p=0.038^{*}, \mathrm{~b}-p= \\
<0.00001^{*}, \mathrm{c}-p= \\
0.02^{*}, \text { and } \mathrm{d}-p=0.38\end{array}$ \\
\hline $\begin{array}{l}\text { Braakenburg } \\
\text { et al. [7], } \\
2006\end{array}$ & $\begin{array}{l}N=65 \\
\text { patients } \\
\text { (whereof } 19 \\
\text { with } \\
\text { pressure } \\
\text { ulcers) }\end{array}$ & i.n. & $\begin{array}{l}\text { Completely } \\
\text { granulating } \\
\text { wound or } \\
\text { wound ready } \\
\text { for dermoplasty } \\
\text { or wound ready } \\
\text { for secondary } \\
\text { healing }\end{array}$ & $\begin{array}{l}\text { TNP vs wound } \\
\text { protocol } \\
\text { (=hydrocolloid, } \\
\text { alginate, acetic } \\
\text { acid, sodium } \\
\text { hypochlorite) }\end{array}$ & $\begin{array}{l}\text { 1a-wound healing (full } \\
\text { closure or possibility of } \\
\text { closure), } 1 \mathrm{~b} \text {-wound } \\
\text { surface; } 2 \mathrm{a}- \\
\text { granulation tissue } \\
\text { formation, } 2 \mathrm{~b}- \\
\text { bacterial cleaning; } \\
3 \mathrm{a}-\text { wound care time, } \\
3 \mathrm{~b}-\text { cost measurement }\end{array}$ & $\begin{array}{l}1 \mathrm{a}-p=0.32, \text { for diabetic } \\
\text { and cardiovascular } \\
\text { patients } p=0.06 ; 1 \mathrm{~b}- \\
p=0.78 ; 2 \mathrm{a}-p=0.64, \\
2 \mathrm{~b}-p=0.06 ; 3 \mathrm{a}-p= \\
0.04^{*}, 3 \mathrm{~b}-p=0.09 \\
\text { (LVT more expensive } \\
\text { than control) }\end{array}$ \\
\hline $\begin{array}{l}\text { Mouës et al. } \\
\text { [24-26], } \\
\text { 2004-2007 }\end{array}$ & $\begin{array}{l}N=54 \\
\text { patients } \\
\text { (whereof } 20 \\
\text { with } \\
\text { pressure } \\
\text { ulcers) }\end{array}$ & i.n. & $\begin{array}{l}\text { Wound (red, } \\
\text { clean, } \\
\text { granulating) } \\
\text { 'ready' for } \\
\text { surgical therapy } \\
\text { in } 30 \text { days }\end{array}$ & $\begin{array}{l}\text { TNP vs saline } \\
\text { solution, } \\
\text { nitrofuralum, } \\
\text { acetic acid, } \\
\text { sodium } \\
\text { hypochlorite }\end{array}$ & $\begin{array}{l}\text { 1-wound healing; } \\
\text { 2-wound surface; } 3- \\
\text { bacterial cleaning; } 4 \mathrm{a}- \\
\text { costs of dressing } \\
\text { materials, } 4 \mathrm{~b}-\text { costs of } \\
\text { wound care, } 4 \mathrm{c}- \\
\text { hospital costs, } 4 \mathrm{~d}- \\
\text { total treatment costs }\end{array}$ & $\begin{array}{l}1-p=0.19 ; 2-p= \\
<0.05^{*} ; 3 \text {-reduction } \\
\text { nonfermenting Gram- } \\
\text { negative rods } p=<0.05^{*} \\
\text { and increase in } S . \\
\text { aureus } p=<0.05^{*} ; 4 \mathrm{a}- \\
\text { intervention more } \\
\text { expensive } p=0.0001^{*}, \\
\text { 4b-control more } \\
\text { expensive } p=0.0001^{*}, \\
4 \mathrm{c}-\text { control more } \\
\text { expensive } p=0.043^{*}, \\
\text { 4d-not significant }\end{array}$ \\
\hline
\end{tabular}

i.n.: if necessary

completed the study. How the research subjects that dropped out were dealt with (intention-to-treat or per protocol analysis) was not revealed. Also, in three cases, they switched the treatment after 6 weeks to the opposing treatment by which it stays unclear what the effect is of the two wound treatment methods on wound healing.

\section{Effectiveness of TNP}

The results on wound healing varied between the studies. Although all studies showed a favorable effect in the group that received TNP, this was only significant in one study [18] (Table 2). Two studies found a decrease in duration up to the reached end point of wound healing [7,25] of 16 vs 20 days $(p=0.32)$ [7] and 6 vs 7 days $(p=0.19)$ [25] in favor of TNP. Three studies found a decrease in wound volume $[15,18$, $35]$ of $57 \%$ vs $42 \%(p=0.46)$ [15], $78 \%$ vs $30 \%(p=0.038)$ [18], and 27 days vs 28 days to reach $50 \%$ wound volume reduction [35]. The statistically significant results were found in a population with wounds with mixed etiology. The studies that solely included patients with a pressure ulcer did not show statistically significant positive results $[15,35]$. 
In this systematic review, every study has its methodological restrictions. The study that best met the Cochrane quality criteria showed a significant difference in wound healing between TNP and the control group [18]. Rather striking in this study was that, in a Cox proportional hazard model, the covariates 'treatment,' 'wound type,' 'tendon or bone lying bare,' and 'the duration of the wound' were taken into account, but not the initial wound volume, whereas a significant difference was seen between the two treatment groups. The other studies, which had more shortcomings in the quality assessment, also showed differences in favor of the TNP.

\section{Discussion}

For this review, we systematically selected and analyzed five randomized studies in which TNP was used as experimental intervention and different dressing therapies as control intervention. The random samples in these studies consisted entirely or partly of patients with pressure ulcers. Because pressure ulcers are classified as chronic wounds as well, we deliberately included studies which included patients with pressure ulcers as part of a sample with chronic wounds, Therefore, this review comprises a more complete overview of the performed studies in patients with pressure ulcer treated with TNP. Moreover, the studies in patients with chronic wounds were of sound methodological quality. As a result of this, the conclusion of our study is of more importance.

A significant reduction in wound volume was found only once [18]. A significant reduction in wound surface was also found only once [25]. In both studies, patients with pressure ulcers were part of the total random sample. None of the selected RCTs revealed a statistically significant increase in granulation tissue.

All of the analyzed studies had methodological shortcomings. Blinding the patients for the treatment is practically unfeasible and blinding the physicians for the TNP is not possible because of the obvious visible suction marks in the wound. This cannot be seen as a shortcoming. All the other shortcomings mentioned in Table 1 are, however, preventable.

Further underpinning of this conclusion by means of a metaanalysis of the selected material was not possible. First of all, there were only two RCTs $[15,35]$ in which the entire random sample consisted of patients with pressure ulcers. In the three other RCTs [7, 18, 25-27], the patients with pressure ulcers were part of random samples of patients with a mix of chronic and/or acute wounds. None of the studies did a subgroup analysis of the pressure ulcer patients, probably due to lack of power.

A second reason for not conducting a metaanalysis was the great diversity in control interventions between and within the studies. Two studies compared TNP with one intervention: saline solution [18] or Ringer's solution [35]. In three studies [7, 15, 25-27], several interventions were used at the same time, whether according to departmental protocols. It was not clear in these studies whether the choice of control intervention was made by the care providers, treating physicians, or the researchers. The choice of the correct dressing by care providers and treating physicians often leaves much to be desired [20] and depends on experience [21]. Deviant use of TNP can also affect the outcome of research. In all studies, the experimental intervention consisted of the VAC ${ }^{\circledR}$ therapy of KCI Medical Products. It was recommended to change the foam suction dressing once every $48 \mathrm{~h}[2,3]$. Wanner et al. [35] changed the dressings between 2 and 7 days and this depended on the amount of exudate collected by the collection system. One of the reasons for changing the foam suction dressing once every $48 \mathrm{~h}$ is to prevent young granulation tissue from growing into the foam suction dressing. The longer the dressing remains in place, the greater the unnecessary loss of granulation tissue during the changing of the dressing [3].

A rather difficult aspect in the qualitative comparison of these studies is the difference in end points. For this, different measurements are used. The main difference between these measurements is the change in wound dimensions (volume, surface, and the determinants thereof: length, width, and depth) or the speed with which, or time in which, this change occurs. The statistical test in which the speed is tested in which a defined end point is reached is the Kaplan-Meier method, if required controlling for the effect of covariables by means of a Cox regression model. This technique was applied in three selected RCTs [7, 18, 25-27]. Particularly, the careful selection and measurement of any covariables is essential. Of all things, the large difference in initial wound volume in the study by Joseph et al. [18] was not included as a covariable in the Cox proportional hazard model.

An important covariable is the type of wound. In three studies [7, 18, 25-27], the random sample consists of patients with wounds with mixed etiology. Pressure ulcer is part of this selection. Various wound healing aspects of a chronic wound are different from those of an acute or subacute wound [22]. It is therefore essential that, in studies on the effects of different interventions in patients with wounds with mixed etiology, subgroup analyses are carried out or that the type of wound is taken into account as covariable in the analysis.

The difference in random sample size between the five studies varied from 22 to 65 patients. Only those studies with a random sample size of 54 [25-27] and 65 patients [7] were based on the prior calculation of the random sample size required to obtain a statistically significant 
result for an assumed relevant effect. This might indicate that the three other studies $[15,18,35]$ with a random sample size varying between 22 and 28 had insufficient power. Another major difference was the randomization. In three studies [7, 15, 35], the patients were randomized across the different interventions. In the other two studies $[18,25-27]$, the wounds were randomized across the different interventions, and in one case, it happened that a patient with multiple wounds received multiple interventions. As others suggested [13], it is preferable to use a single reference wound. It makes it in any case practically impossible to check if the randomization is successful because the patient characteristics against which this should be checked are no longer independent for the patients receiving multiple interventions. This independence is also a problem in multivariate analysis.

\section{Conclusion}

On the basis of this review of five RCTs on the effectiveness of TNP in patients with pressure ulcers, it must be concluded that TNP has not been proven to be more effective than various control interventions. The differences in control interventions between and within the studies, the differences in randomization, and a number of weaknesses in the analysis did not allow a good comparison. The main recommendations for follow-up study are randomization of patients rather than of wounds, a homogeneous patient population, use of a single welldefined and procedurally documented control intervention, and prior calculation of the random sample size.

Open Access This article is distributed under the terms of the Creative Commons Attribution Noncommercial License which permits any noncommercial use, distribution, and reproduction in any medium, provided the original author(s) and source are credited.

\section{References}

1. European Pressure Ulcer Advisory Panel (1998) Pressure ulcer prevention guidelines. Available at http://www.epuap.org/glprevention. html

2. Argenta LC, Morykwas MJ (1997) Vacuum-assisted closure: a new method for wound control and treatment: clinical experience. Ann Plast Surg 38(6):563-576 Jun

3. Banwell PE (1999) Topical negative pressure therapy in wound care. J Wound Care 8(2):79-84 Feb

4. Banwell PE, Teot L (2003) Topical negative pressure (TNP): the evolution of a novel wound therapy. J Wound Care 12(1):22-28 Jan

5. Bennett G, Dealey C, Posnett J (2004) The cost of pressure ulcers in the UK. Age Ageing 33(3):230-235 May

6. Bours GJ, Halfens RJ, Abu-Saad HH, Grol RT (2002) Prevalence, prevention, and treatment of pressure ulcers: descriptive study in 89 institutions in the Netherlands. Res Nurs Health 25(2):99-110 Apr
7. Braakenburg A, Obdeijn MC, Feitz R, van Rooij IA, van Griethuysen AJ, Klinkenbijl JH (2006) The clinical efficacy and cost effectiveness of the vacuum-assisted closure technique in the management of acute and chronic wounds: a randomized controlled trial. Plast Reconstr Surg 118(2):390-397 Aug

8. Cardozo M (2003) A case study of holistic wound management in intensive care. Br J Nurs 12(11 Suppl):S35-S32 Jun

9. CBO kwaliteitsinstituut voor de Gezondheidszorg. Decubitus. Tweede herziening. Alphen aan den Rijn: Uitgever Van Zuiden communications B.V.; 2002. Report No.: publicatie 2002

10. Demaria RG, Giovannini UM, Teot L, Frapier JM, Albat B (2003) Topical negative pressure therapy. A very useful new method to treat severe infected vascular approaches in the groin. J Cardiovasc Surg (Torino) 44(6):757-761 Dec

11. Deva AK, Buckland GH, Fisher E, Liew SC, Merten S, McGlynn M et al (2000) Topical negative pressure in wound management. Med J Aust 173(3):128-131 Aug 7

12. European Pressure Ulcer Advisory Panel (1992) Pressure ulcers in adults: prediction and prevention. Agency for Health Care Policy and Research. J ET Nurs 19(5):176-180 Sep

13. Evans D, Land L (2004) Topical negative pressure for treating chronic wounds. The Cochrane Library, Issue 1. Wiley, Chichester, UK

14. Fleischmann W, Russ M, Westhauser A, Stampehl M (1998) Die Vakuumversiegelung als Tragersystem fur eine gezielte lokale Medikamentenapplikation bei Wundinfektionen. [Vacuum sealing as carrier system for controlled local drug administration in wound infection]. Unfallchirurg 101(8):649-654 Aug

15. Ford CN, Reinhard ER, Yeh D, Syrek D, Las-Morenas A, Bergman SB et al (2002) Interim analysis of a prospective, randomized trial of vacuum-assisted closure versus the healthpoint system in the management of pressure ulcers. Ann Plast Surg 49(1):55-61 Jul

16. Greene AK, Puder M, Roy R, Arsenault D, Kwei S, Moses MA et al (2006) Microdeformational wound therapy: effects on angiogenesis and matrix metalloproteinases in chronic wounds of 3 debilitated patients. Ann Plast Surg 56(4):418-422 Apr

17. Hutchinson L, Thompson J (1999) Vacuum-assisted closure: a method of facilitating wound healing. World Counc Enteros Ther J 19:17-21

18. Joseph E, Hamori CA, Bergman S, Roaf E, Swann NF, Anastasi GW (2000) New therapeutic approaches in wound care. A prospective randomized trial of vacuum-assisted closure versus standard therapy of chronic nonhealing wounds. Wounds 12(3):60-67 May

19. Kamolz LP, Andel H, Haslik W, Winter W, Meissl G, Frey M (2004) Use of subatmospheric pressure therapy to prevent burn wound progression in human: first experiences. Burns 30(3):253-258 May

20. King BM (2000) Assessing nurses' knowledge of wound management. J Wound Care 9(7):343-346 Jul

21. Lamond D, Farnell S (1998) The treatment of pressure sores: a comparison of novice and expert nurses' knowledge, information use and decision accuracy. J Adv Nurs 27(2):280-286 Feb

22. Menke NB, Ward KR, Witten TM, Bonchev DG, Diegelmann RF (2007) Impaired wound healing. Clin Dermatol 25(1):19-25 Jan

23. Morykwas MJ, Argenta LC (1997) Nonsurgical modalities to enhance healing and care of soft tissue wounds. J South Orthop Assoc 6(4):279-288

24. Morykwas MJ, Argenta LC, Shelton-Brown EI, McGuirt W (1997) Vacuum-assisted closure: a new method for wound control and treatment: animal studies and basic foundation. Ann Plast Surg 38(6):553-562 Jun

25. Mouës CM, Van Den Bemd GJ, Heule F, Hovius SE (2007) Comparing conventional gauze therapy to vacuum-assisted closure wound therapy: a prospective randomised trial. J Plast Reconstr Aesthet Surg 60(6):672-681 Jun

26. Mouës CM, Van Den Bemd GJ, Meerding WJ, Hovius SE (2005) An economic evaluation of the use of TNP on full-thickness wounds. J Wound Care 14(5):224-227 May 
27. Mouës CM, Vos MC, Van Den Bemd GJ, Stijnen T, Hovius SE (2004) Bacterial load in relation to vacuum-assisted closure wound therapy: a prospective randomized trial. Wound Repair Regen 12(1):11-17 Jan

28. Mullner T, Mrkonjic L, Kwasny O, Vecsei V (1997) The use of negative pressure to promote the healing of tissue defects: a clinical trial using the vacuum sealing technique. Br J Plast Surg 50(3):194-199 Apr

29. Obdeijn MC, de Lange MY, Lichtendahl DH, de Boer WJ (1999) Vacuum-assisted closure in the treatment of poststernotomy mediastinitis. Ann Thorac Surg 68(6):2358-2360 Dec

30. Paul JC (2005) Vacuum assisted closure therapy: a must in plastic surgery. Plast Surg Nurs 25(2):61-65 Apr

31. Schoonhoven L, Bousema MT, Buskens E (2006) The prevalence and incidence of pressure ulcers in hospitalised patients in The Netherlands: a prospective inception cohort study. Int J Nurs Stud 44:927-935 Apr
32. Severens JL, Habraken JM, Duivenvoorden S, Frederiks CM (2002) The cost of illness of pressure ulcers in The Netherlands. Adv Skin Wound Care 15(2):72-77 Mar

33. Smith N (2004) The benefits of VAC therapy in the management of pressure ulcers. Br J Nurs 13(22):1359-1365 Dec 9

34. Venturi ML, Attinger CE, Mesbahi AN, Hess CL, Graw KS (2005) Mechanisms and clinical applications of the vacuumassisted closure (VAC) device: a review. Am J Clin Dermatol 6 (3):185-194

35. Wanner MB, Schwarzl F, Strub B, Zaech GA, Pierer G (2003) Vacuum-assisted wound closure for cheaper and more comfortable healing of pressure sores: a prospective study. Scand J Plast Reconstr Surg Hand Surg 37(1):28-33

36. Webb LX, Schmidt U (2001) Wundbehandlung mit der Vakuumtherapie. Unfallchirurg 104(10):918-926 Oct 